\title{
Hubungan Cerebral Palsy Spastik Dengan Flexion Posture
}

\author{
${ }^{1)}$ Siti Khadijah, ${ }^{2)}$ Adnan Faris Naufal
}

${ }^{1,2)}$ Program Studi Fisioterapi, Fakultas Ilmu Kesehatan, Universitas Muhammadiyah Surakarta

Jl. A. Yani Tromol Pos I Pabelan Kartasura Telp. (0271) 717417 Fax. (0271) 715448 Surakarta 57162

email: stkhadijah0110@gmail.com

Tanggal Submisi: 27 Januari 2020; Tanggal Penerimaan: 6 Februari 2020

\begin{abstract}
ABSTRAK
Latar Belakang: Reflek primitif berpengaruh terhadap voluntary movement dan postural. Tipe postural pada anak CP dibagi menjadi 2 yaitu tipe fleksi (flexion posture) dan ekstensi (extension posture). Adanya hipereksitasi saraf pada bagian kelompok otot fleksor menyebabkan postur CP spastik ke arah fleksi (flexion posture).

Tujuan Penelitian: Untuk mengetahui hubungan CP spastik dengan flexion posture.

Metode Penelitian: Penelitian ini menggunakan cross-sectional study yang dilakukan satu kali pada satu waktu dan tidak ada follow up. Subjek penelitian sebanyak 26 anak CP yang dilaksanakan di PNTC Tohudan, YPAC Surakarta, dan Klinik Intan Fisioterapi Anak Ngemplak.

Hasil Penelitian: Hasil dari penelitian ini setelah diuji statistika diperoleh adanya hubungan CP spastik dengan flexion posture dengan nilai $p=0.005$ ( $p<0.05$ ).

Kesimpulan: Terdapat hubungan antara klasifikasi CP spastik dengan flexion posture.
\end{abstract}

Kata kunci: Cerebral palsy, Reflek primitif, Flexion posture

\section{ABSTRACT}

Background: Primitive reflexes influence voluntary movement and postural. Postural types in CP children are divided into 2 types, namely flexion type and extension posture. The presence of nerve hyperexitation in the flexor muscle group causes a spastic CP posture toward flexion.

Objectives: To determine the relationship of spastic CP with flexion posture.

Methods: This study used a cross-sectional study that was conducted once at a time and there was no followup. Research subjects were 26 CP children who were carried out at PNTC Tohudan, YPAC Surakarta, and the Ngemplak Children's Physiotherapy Clinic.

Results: The results of this study after being tested statistically obtained an association of spastic CP with flexion posture with $p=0.005$ ( $p<0.05)$.

Conclusion: There is a relationship between spastic CP classification and flexion posture.

Keywords: Cerebral palsy, Primitive reflexes, Flexion posture

\section{PENDAHULUAN}

Cerebral palsy $(\mathrm{CP})$ termasuk onset pediatri kecacatan fisik yang paling umum terjadi. CP disebabkan oleh malformasi perkembangan otak yang mempengaruhi pusat kontrol motorik sehingga mengarah kepada perubahan pertumbuhan dan perkembangan (Verschuren et al., 2018).

Menurut Levitt (2010) CP spastik merupakan suatu kondisi dengan karakteristik hipertonus pada tonus otot sehingga menyebabkan kekakuan otot. Kemudian diikuti dengan adanya abnormalitas postural.

Menurut Sindou et al (2014) reflek primitif berpengaruh terhadap voluntary movement dan postural. Tipe postural pada anak CP dibagi menjadi 2 yaitu tipe fleksi (flexion posture) dan ekstensi (extension posture). Adanya hipereksitasi saraf pada bagian kelompok otot fleksor menyebabkan 
postur CP spastik ke arah fleksi (flexion posture).

Menurut Press (2014) tipe postural pada anak CP ialah postural yang atipikal. Flexion posture disebabkan karena gangguan pada eksitatoric post synaptic potential (monosynaptic pathway) sehingga terjadinya kontraksi otot yang berlebihan (Brashear, 2016). Extension posture disebabkan karena terjadinya kerusakan pada basal ganglia sehingga seseorang sulit untuk melakukan gerakan-gerakan halus dan tangkas pada anggota gerak atas dan bawah pada sisi tubuh yang berlawanan (Snell, 2010).

Tipe postural pada anak $\mathrm{CP}$ dibagi menjadi 2 yaitu tipe fleksi (flexion posture) dan ekstensi (extension posture). Kondisi ini diperkuat dengan adanya reflek primitif yang dominan pada salah satu kelompok otot fleksor yaitu symmetrical tonic neck reflex (STNR) yang disebabkan kerusakan pada sistem piramidalis. Sedangkan pada CP atetoid adanya reflek primitif yang dominan pada kelompok otot ekstensor yaitu asymmetrical tonic neck reflex (ATNR) menyebabkan postural ke arah ekstensi karena kerusakan pada sistem ekstrapiramidalis (Dias \& Dias, 2017).

Rumusan masalah dari penelitian ini adalah apakah ada hubungan CP spastik dengan flexion posture. Sedangkan tujuan dari penelitian ini ialah untuk mengetahui hubungan CP spastik dengan flexion posture. Manfaat dari penelitian ini yaitu dapat memberikan informasi kepada masyarakat tentang hubungan $\mathrm{CP}$ spastik dengan flexion posture dan diharapkan sebagai acuan dalam penanganan fisioterapi sebelum menentukan klasifikasi tipe postural pada anak CP.

\section{METODE PENELITIAN}

Penelitian ini menggunakan crosssectional study yang dilakukan satu kali pada satu waktu dan tidak ada follow up (Levin, 2014). Penelitian ini bertujuan untuk mencari hubungan antara variabel independent dan variabel dependent dengan melakukan pengukuran dalam satu waktu (Setia, 2018). Variabel independent dari penelitian ini adalah $\mathrm{CP}$ spastik dan variabel dependent ialah flexion posture.

Tempat pelaksanaan penelitan terdiri dari 3 lokasi yaitu di klinik PNTC (Pediatrics Neurodevelopmental Therapy Center) di Tohudan, YPAC (Yayasan Penyandang Anak Cacat) di Surakarta, dan Klinik Intan Fisioterapi Anak di Ngemplak, Jawa Tengah. Populasi dari penelitian ini adalah semua pasien yang ada di klinik PNTC Tohudan, YPAC Surakarta, dan Klinik Intan Fisioterapi Anak di Ngemplak yang terdiri dari 26 orang.

Kriteria inklusi pada penelitian ini yaitu a) anak dengan kondisi CP spastik diplegi, hemiplegi, dan quadriplegi) dengan nilai spastisitas 1 sampai dengan 4, b) anak usia 110 tahun, dan c) anak yang bersedia menjadi sampel penelitian. Kriteria eksklusi penelitian ini yaitu a) anak dengan kondisi CP flaccid, b) anak dengan kondisi spastik atetoid, c) anak CP dengan nilai spastisitas 0 , dan d) anak yang tidak bersedia menjadi sampel penelitian. Gambaran CP spastik dijelaskan pada Gambar 1 .

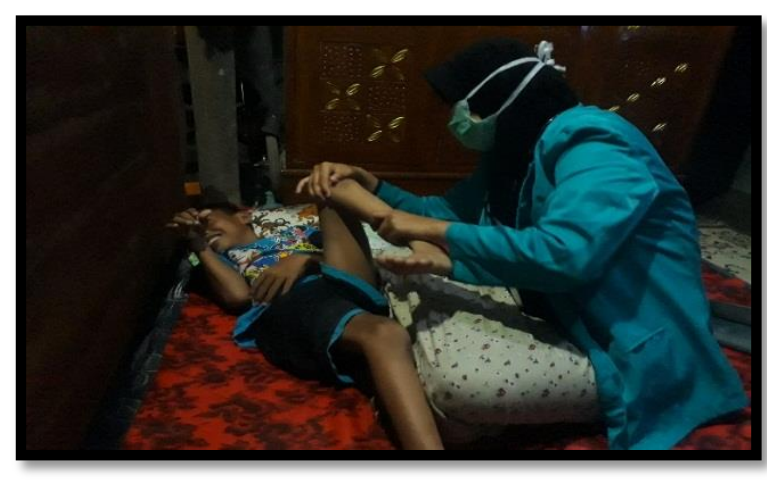

Gambar 1. CP Spastik (Dokumentasi Pribadi, 2019).

Peneliti sedang melakukan pengukuran spastisitas dengan menggunakan asworth scale. 


\section{HASIL}

\section{Distribusi Responden}

Tabel 1. Hasil Distribusi Usia Responden

\begin{tabular}{clcc}
\hline No & \multicolumn{1}{c}{ Usia } & Jumlah & Persentase \\
\hline 1 & 1 tahun & 1 & $3.84 \%$ \\
2 & 2 tahun & 3 & $11.5 \%$ \\
3 & 3 tahun & 3 & $11.5 \%$ \\
4 & 4 tahun & 2 & $3.96 \%$ \\
5 & 5 tahun & 1 & $3.84 \%$ \\
6 & 6 tahun & 2 & $3.96 \%$ \\
7 & 7 tahun & 3 & $11.5 \%$ \\
8 & 8 tahun & 3 & $11.5 \%$ \\
9 & 9 tahun & 3 & $11.5 \%$ \\
10 & 10 tahun & 5 & $19.2 \%$ \\
& Total & 26 & $100 \%$ \\
\hline
\end{tabular}

Tabel 2. Hasil Distribusi Jenis Kelamin Responden

\begin{tabular}{ccc}
\hline Jenis Kelamin & Jumlah & Persentase \\
\hline Laki-laki & 5 & $19.2 \%$ \\
Perempuan & 21 & $80.7 \%$ \\
Total & 26 & $100 \%$ \\
\hline
\end{tabular}

Tabel 3. Hasil Distribusi Klasifikasi CP Responden

\begin{tabular}{cccc}
\hline No & Klasifikasi CP & Jumlah & Persentase \\
\hline 1 & Spastik & 26 & $100 \%$ \\
& Total & 26 & $100 \%$ \\
\hline
\end{tabular}

Tabel 4. Hasil Distribusi Klasifilkasi CP berdasarkan Usia

\begin{tabular}{ccccccccccccc}
\hline & & \multicolumn{10}{c}{ Usia } & \multirow{2}{*}{ Total } \\
\cline { 2 - 10 } Klasifikasi & Spastik & 1 & 2 & 3 & 4 & 5 & 6 & 7 & 8 & 9 & 10 & \\
\cline { 2 - 10 } & Grade I & 0 & 1 & 0 & 1 & 0 & 0 & 0 & 3 & 1 & 0 & 6 \\
& Grade 2 & 0 & 2 & 1 & 1 & 0 & 0 & 2 & 0 & 0 & 0 & 6 \\
Grade 3 & 0 & 0 & 1 & 0 & 0 & 1 & 0 & 0 & 1 & 4 & 7 \\
Grade 4 & 0 & 0 & 0 & 0 & 0 & 0 & 1 & 0 & 1 & 5 & 7 \\
Total & 1 & 3 & 2 & 2 & 1 & 1 & 3 & 3 & 3 & 9 & 26 \\
\hline
\end{tabular}

Tabel 5. Hasil Distribusi Tipe Postural Responden

\begin{tabular}{ccc}
\hline \multirow{2}{*}{ Usia } & \multicolumn{2}{c}{ Tipe Postural } \\
\cline { 2 - 3 } & Reflek ATNR & Reflek STNR \\
\hline 1 tahun $(n=1)$ & 1 & 0 \\
$2 \operatorname{tahun}(\mathrm{n}=3)$ & 0 & 1 \\
3 tahun $(\mathrm{n}=3)$ & 2 & 2 \\
$4 \operatorname{tahun}(\mathrm{n}=2)$ & 0 & 0 \\
5 tahun $(\mathrm{n}=1)$ & 1 & 1 \\
6 tahun $(\mathrm{n}=2)$ & 1 & 1 \\
7 tahun $(\mathrm{n}=3)$ & 2 & 1 \\
$8 \operatorname{tahun}(\mathrm{n}=3)$ & 2 & 2 \\
$9 \operatorname{tahun}(\mathrm{n}=3)$ & 1 &
\end{tabular}




\begin{tabular}{ccc}
10 tahun $(\mathrm{n}=5)$ & 1 & 4 \\
Total & 11 & 15 \\
\hline
\end{tabular}

Tabel 6. Hasil Distribusi Tipe Postural Berdasarkan CP

\begin{tabular}{ccc}
\hline \multirow{2}{*}{ Tipe Postural } & Total \\
\cline { 3 - 3 } Reflek ATNR & Spastik \\
Reflek STNR & $7(26.9 \%)$ \\
Total & $19(73.0)$ \\
\hline
\end{tabular}

\section{Hasil Analisis Data}

Tabel 7. Uji Chi-Square CP Spastik dengan Flexion Posture

\begin{tabular}{cccccc}
\hline \multirow{2}{*}{$\begin{array}{c}\text { Klasifikasi } \\
\text { CP }\end{array}$} & \multicolumn{2}{c}{ Tipe Postural } & Peflek \\
\cline { 2 - 4 } & ATNR & $\begin{array}{c}\text { Reflek } \\
\text { STNR }\end{array}$ & $d f$ & Palue & Kesimpulan \\
\hline $\begin{array}{c}\text { Spastik } \\
(\mathrm{n}=26)\end{array}$ & 7 & 19 & 1 & 0.005 & Ho ditolak \\
\hline
\end{tabular}

Berdasarkan Tabel diketahui $\mathrm{p}=0.005(\mathrm{p}<0.05)$ sehingga terdapat hubungan CP spastik dengan flexion posture.

\section{PEMBAHASAN}

Berdasarkan dengan hasil penelitian bahwa terdapat hubungan $\mathrm{CP}$ spastik dengan flexion posture. Klasifikasi $\mathrm{CP}$ atetoid lebih rendah prevalansinya dibandingkan dengan klasifikasi CP spastik dan ataksia. CP atetoid hanya terjadi $<10 \%$ dari angka kejadian. Sedangkan CP spastik terjadi sebanyak $70 \%$ dan CP ataksia 6-10\% dari angka kejadian (Kumar \& Parveen, 2018). Hasil penelitian ini didukung oleh penelitian yang dilakukan Wagh et al (2019) pada 40 anak CP yang terdiri dari 21 laki-laki dan 19 perempuan dengan rentang umur 12-24 bulan. Hasil penelitian ini menjelaskan bahwa $\mathrm{p}<0.0001$, sehingga adanya hubungan reflek primitif dengan perkembangan motorik yang ditandai adanya reflek palmar grasp yang diikuti dengan reflek ATNR sebanyak $80 \%$. Sehingga terdapat hubungan antara reflek primitif dengan perkembangan motorik pada anak $\mathrm{CP}$.

Pada kondisi flexion posture munculnya reflek primitif yang dominan pada salah satu kelompok otot fleksor dari otot anti gravitasi yaitu reflek STNR. Munculnya reflek tersebut disebabkan karena kerusakan pada sistem piramidalis (Dias \& Dias, 2017). Hasil penelitian menunjukkan bahwa sebanyak 19 anak (73.0\%) yaitu klasifikasi CP spastik yang disertai dengan munculnya reflek STNR dari total 26 anak CP spastik. Namun sebanyak 7 anak memiliki reflek ATNR. Banyak faktor yang mempengaruhi reflek primitif pada anak seperti tingkatan gangguan abnormal motor development, penyebab yang tidak diketahui, dan nonprogressive neurological disorder sehingga mempengaruhi kontrol motorik pada anak CP (Aiyejusunle, Olawale, \& Onuegbu, 2016).

\section{KESIMPULAN DAN SARAN}

Berdasarkan dari kajian data dan pembahasan yang telah dijelaskan maka dapat ditarik kesimpulan bahwa adanya hubungan CP spastik dengan flexion posture di PNTC 
Tohudan, YPAC, dan Klinik Intan Fisioterapi Anak di Ngemplak Surakarta.

Diharapkan penelitian ini dapat dilanjutkan sehingga mendapatkan hasil yang lebih efektif dari sebelumnya.

\section{UCAPAN TERIMA KASIH}

Peneliti menyadari tanpa bantuan dan dukungan dari berbagai pihak penyusunan penelitian ini tidak dapat berjalan baik. Dalam hal ini peneliti telah banyak menerima bantuan dan bimbingan moril dan materiil. Maka tim peneliti mengucapkan terimakasih kepada dosen yang telah berkenan membagi ilmu dan pengalaman, seluruh staff PNTC, YPAC, dan Klinik Intan Fisio Anak yang telah membantu dalam sarana dan prasarana penelitian, serta pasien yang sudah berkenan menjadi responden dalam penelitian. Tidak lupa ucapan terimakasih kepada Universitas Muhammadiyah Surakarta Fakultas Ilmu Kesehatan Prodi Fisioterapi yang telah memberikan izin dan pendanaan terkait kegiatan penelitian ini.

\section{DAFTAR PUSTAKA}

Aiyejusunle, C. B., Olawale, O. A., \& Onuegbu, N. F. (2016). Association of selected primitive reflex patterns with motor development among Nigerian children with cerebral palsy ( a hospital - based study ). Journal of Clinical Sciences, 13(1), 12-16. https://doi.org/10.4103/1595-

9587.175481
Brashear, A. (2016). spasticity diasgnosis and management. (A. Brshear, Ed.) (2nd ed.). new york: demosmedical.

Dias, E., \& Dias, A. (2017). Cerebral Palsy : A Brief Review. Academic Journal of Pediatrics and Neonatology, 4(1), 1-3.

Kumar, K. S., \& Parveen, S. (2018). Management and Treatment for Cerebral Palsy in. Indian Journal of Pharmacy Practice, 11(2). https://doi.org/10.5530/ijopp.11.2.23

Levin, K. A. (2014). Study Design III : crosssectional studies Study design III : Cross-sectional studies, (February 2006).

Levitt, S. (2010). Treatment of cerebral palsy and motor delay. (S. Levitt, Ed.) (5th ed.). Wiley-Blackwell.

Press, D. (2014). Postural pattern recognition in children with unilateral cerebral palsy, 113-120.

Setia, M. S. (2018). Methodology Series Module 3: Cross-sectional Studies Methodology Series Module 3 : Crosssectional Studies, (May 2016). https://doi.org/10.4103/00195154.182410.

Sindou, M., Georgoulis, G., Mertens, \& Patrick. (2014). Neurosurgery for Spasticity.

Snell, S. R. (2010). clinical neuroanatomy (7th ed.). wolters 